INDONESIA ACCOUNTING JOURNAL

VOLUME 1, NUMBER 2, YEAR 2019

${ }^{1}$ Corresponding author

Jurusan Akuntansi

Fakultas Ekonomi dan Bisnis

Universitas Sam Ratulangi

Jl. Kampus UNSRAT

Manado, Indonesia, 95115

E-mail: meylineparera691@gmail.com

${ }^{2,3}$ Jurusan Akuntansi

Fakultas Ekonomi dan Bisnis

Universitas Sam Ratulangi

Jl. Kampus UNSRAT

Manado, Indonesia, 95115

Article info:

Received 20 December 2019

Accepted 20 December 2019

Available online 20 December 2019

Keywords: internal control; control procedures; cash disbursement; internal control structure; five elements SPIP

JEL Classification: $\mathrm{H}_{3}$, M41

DOI: http://doi.org/10.32400/iaj.26814

\section{Sistem pengendalian intern pengeluaran kas pada Sekretariat Daerah Kabupaten Kepulauan Sangiheə}

\author{
Meyline Trisuksi Parera ${ }^{1}$ \\ Lintje Kalangi ${ }^{2}$ \\ Novi Swandari Budiarso ${ }^{3}$
}

\begin{abstract}
The internal control system has an internal control structure that can control the internal control process including the control environment, accounting system, control procedures. This study aims to determine the internal control system, especially in cash disbursement activities at the Sangihe Regency Regional Secretariat which is based on the 5 (five) elements of the SPIP (government internal control system) including, control environment, risk assessment, control activities, information and communication and monitoring. The type of data used is qualitative data by conducting observations and direct interviews at the Regional Secretariat Office of the Sangihe Regency to the head of the financial subsection who knows thoroughly about cash disbursements. The results of the research obtained on the internal control system related to cash disbursements at the Regional Secretariat of the Sangihe Regency are in accordance with the 5 (five) elements of the Government Internal Control System (SPIP).
\end{abstract}

\section{Pendahuluan}

Seiring dengan perkembangan pada era globalisasi tentang sistem pengendalian intern, perangkat daerah didorong untuk melakukan penyesuaian dengan perkembangan tersebut. Kinerja para Aparatur Sipil Negara (ASN) yang memiliki dasar keberhasilan dalam menjalankan tugas dan fungsi pada pemerintahan saat ini di Kantor Sekretariat Daerah Kabupaten Kepulauan Sangihe. Perkembangan kinerja menjadi dasar keberhasilan tugas dan fungsi pada pemerintahan yang sedang berjalan pada Sekretariat Daerah Kabupaten Kepulauan Sangihe. Pimpinan ataupun pengawas bisa mengetahui baik dan buruknya proses pekerjaan dengan menerapkan pengendalian intern di lingkup pemerintah. Sistem pengendalian intern harus dirancang dengan baik karena salah satu fungsi sistem pengendalian intern adalah menjaga kekayaan atau aset pada organisasi dan lembaga pemerintahan. Pengawasan pada data laporan keuangan bisa mondorong efisiensi dan laporan keuangan yang baik.

$$
\text { Menurut Mulyadi }
$$
pengendalian intern adalah sebuah wilayah kerja yang memiliki bagian masing-masing dalam mendukung proses internal pada suatu organisasi, khususnya pada organisasi pemerintahan. Sedangkan sistem pengendalian intern yaitu keterkaitan antara satu dengan yang lain dalam mencapai tujuan pada bidang pengelolaan keuangan. Lembaga pemerintah memiliki sistem akuntansi, yaitu sistem pengeluaran kas yang mengontrol langsung setiap transaksi kas yang keluar. Jika terjadi penyelewengan misalnya kesalahanan dalam pencatatan atau ketidaksesuaian dengan kebijakan yang berlaku. Hal ini harus dipertanggungjawabkan oleh Bendahara 
yang mengelola dokumen pengeluaran kas, pada pemeriksaan yang dilakukan oleh Inspektorat Kabupaten Kepulauan yang diadakan Badan Pemeriksa Keuangan (BPK) pada setiap periode. Jenis-jenis Opini pemeriksaan terdiri atas: Opini tidak menyatakan pendapat (disclaimer opinion), opini tidak wajar (adverse opinion), opini wajar tanpa pengecualian (unqualified opinion). Tunggal (2016,1) mendefinisikan bahwa pengendalian internal adalah kebijakan atau prosedur yang dijalankan oleh dewan komisaris, manajemen atau personel lain dari suatu entitas dalam meciptakan keyakinan dalam pencapaian suatu tujuan dengan didukung oleh laporan keuangan terpercaya dan kepatuhan pada peraturan yang berlaku.

\section{Tinjauan pustaka}

\section{Pengertian Sistem Pengendalian}

Intern. Secara umum pengendalian intern adalah bagian dari masing-masing sistem yang berfungsi sebagai pedoman dalam setiap pelaksanaan kegiatan pada lembaga pemerintah (Mulyadi 2013). Sistem pengendalian intern adalah sekumpulan prosedur dari pengendalian intern yang saling mendukung satu dengan yang lain dan bertujuan memeriksa ketelitian informasi akuntansi (Mardi 2011,59).

Peraturan Pemerintah nomor 60 tahun 2008 menyatakan, sistem pengendalian intern adalah proses yang terintegrasi pada setiap kegiatan yang dilakukan terusmenerus oleh pimpinan dan seluruh pegawai dalam membangun kepercayaan atas tercapainya tujuan organisasi melalui kegiatan yang efektif dan efisien, keandalan pelaporan, pengamanan pada aset negara dan ketaatan pada perundang-undangan. Menurut Oitun dan Budiarso (2016) komponen yang harus diperhatikan pada prosedur pada akuntansi pengeluaran kas adalah fungsi yang terkait, dokumen yang digunakan, laporan yang dihasilkan dan uraian teknis prosedur. PP No. 71 tahun 2010 mengenai standar akuntansi pemerintah (SAP), sistem akuntansi pemerintah berbasis akrual adalah yang mengakui pendapatan, belanja dan pembiayaan berbasis kas serta mengakui aset, utang dan ekuitas dana berbasis akrual. Unsur Sistem Pengendalian Intern Pemerintah (SPIP) menurut Peraturan Pemerintah nomor 60 tahun 2008, adalah:

1. Lingkungan Pengendalian (control environment).

Lingkungan pengendalian adalah dasar dari semua komponen pengendalian intern, karena mengatur proses kegiatan yang terjadi, memberikan arahan pada setiap organisasi dalam pencapaian tujuan.

2. Penaksiran Risiko (risk assessment).

Penaksiran risiko berbicara mengenai bagaimana suatu perangkat pemerintah bisa mengetahui berbagai risiko apa yang akan muncul dalam berbagai kegiatan.

3. Aktivitas Pengendalian (control activities). Aktivitas pengendalian adalah kebijakan dan prosedur yang menjamin bahwa setiap penyampaian dan peraturan dipatuhi dengan baik pada Organisasi Pemerintah Daerah (OPD) agar tujuan dapat tercapai dan proses kegiatan berjalan sesuai dengan tugas dan fungsinya masing-masing.

4. Informasi dan Komunikasi (information and communication).

Informasi dan komunikasi adalah sistem yang memungkinkan entitas atau OPD dalam pengidentifikasian dan memperoleh atau menukar informasi yang diperlukan untuk melaksanakan, mengelola, dan mengendalikan operasinya agar tidak terjadi penyelewengan atau kesalahan dalam kegiatan yang berlangsung.

5. Pemantauan (monitoring).

Pemantauan atau pengawasan adalah aktivitas yang harus dilakukan dan bertujuan untuk menilai mutu kinerja sistem sepanjang waktu atau menentukan mutu kinerja. Unsur pemantauan ini dijalankan melalui aktivitas pemantauan yang terusmenerus, evaluasi yang terpisah atau kombinasi dari keduanya.

Pengendalian Intern Pengeluaran Kas. Menurut Syarifudin (2014:32) pengendalian intern adalah pengontrolan 
atau struktur organisasi, yang memiliki metode dalam menjaga aset, mengontrol laporan keuangan dan menciptakan kinerja yang baik. Adapun pengendalian intern yaitu pengendalian administrasi yakni pengontrolan pada bagian non-keuangan yang lebih merujuk pada kepatuhan peraturan dan ketelitian dan pengendalian akuntansi biasa kita kenal dengan pengendalian dalam proses laporan keuangan khususnya proses pengeluaran kas yang menjadi pembahasan saat ini ini.

Pengertian Kas. Menurut Kabuhung (2013) kas termasuk dalam aset lancar yang memiliki banyak fungsi yang paling dibutuhkan dalam kegiatan pembayaran diinstansi mana saja. Kas yang ada harus diatur sesuai kebutuhan agar tidak ada uang kas yang menganggur dan bisa menimbulkan penggunaan yang tidak wajar atau kecurangan . Menurut Effendi (2013:191) kas adalah aktiva lancar yang memiliki pengaruh yang sangat baik bagi perekonomian pada setiap perangkat pemerintah daerah dan memiliki pengaruh yang sangat buruk jika disalah gunakan atau dimanipulasi. Kas berbentuk uang yang memiliki jumlah tertentu yang dapat digunakan untuk membiayai kebutuhan dalam aktivitas pada instansi pemerintah.

Pengertian Pengeluaran Kas. Menurut Mulyadi (2016:425) pengeluaran kas harus menggunakan cek, tetapi jika pengeluaran kas dalam jumlah kecil tidak perlu menggunakan cek. Manfaat dalam menggunakan cek adalah menjamin keamanan dalam pengeluaran kas karena setiap transaksi yang dilakukan akan dicatat secara andal.

Sistem Akuntansi Pengeluaran Kas. Menurut Tuerah (2013:4) kas adalah unsur yang sangat penting dalam lingkup pemerintah. Kas tidak bisa dipisahkan dari setiap kegiatan lingkup pemerintah, jumlah kas harus berdasarkan dengan perencanaan penggunaan angaran, pengelolaan kas harus diawasi dengan baik dari proses perencanaan, penerimaan dan pengeluaran kas. Agar tidak ada dana kas yang akan menimbulkan kecurangan yang bisa menghambat kegiatan pada lingkup pemerintah

\section{Metode penelitian}

Jenis Penelitian. Jenis penelitian ini menggunakan jenis data kualitatif dengan metode deskriptif. Penelitian dengan metode deskriptif ini, dilakukan dengan cara mendatangi langsung tempat objek penelitian yaitu pada Sekretariat Daerah Kabupaten Kepulauan Sangihe dengan maksud dan tujuan agar bisa memperoleh data-data dan informasi yang memiliki kaitannya dengan penelitian ini. Data deskriptif yang dikumpulkan berupa wawancara dan observasi. Tempat penelitian di kota Tahuna pada Sekretariat Daerah Kabupaten Kepulauan Sangihe. Penelitian ini di mulai dalam jangka waktu dari bulan Mei-Juli Tahun 2019. Penelitian ini adalah suatu karya ilmiah yang disusun dengan menggunakan jenis, sumber dan metode pengumpulan data, agar setiap data bisa dipertanggungjawabkan sesuai dengan pengelolaan data yang diperoleh. Berikut ini adalah penjelasan mengenai jenis, sumber data, dan metode pengumpulan data yang digunakan. Menurut Sugiyono (2016) jenis data ada dua kualitatif dan kuantitatif. Jenis data yang digunakan adalah jenis data kualitatif yang secara umum data-data bukan terdiri dari angka tetapi data-data yang diperoleh dari survei langsung pada Sekretariat Daerah Kabupaten Kepulauan. Data Primer adalah data yang digunakan pada penelitian ini. Ada 3 (tiga) metode pengumpulan data yang digunakan dalam penelitian ini adalah Observasi, Wawancara, Dokumentasi.

Metode \& Proses Analisis Data. Metode analisis data yang dilakukan dalam penelitian ini adalah metode analisis data deskriptif yaitu dengan mengumpulkan semua data yang telah didapatkan dari penelitian yang dilakukan antara lain dari hasil observasi, jawaban dari wawancara langsung, maupun catatan-catatan yang diperoleh langsung dari lapangan, didukung oleh dokumentasi yang ada agar bisa dipahami, dan hasil penelitian bisa menjadi manfaat bagi pembaca. 


\section{Hasil penelitian dan pembahasan \\ Hasil Penelitian}

Berdasarkan hasil penelitian ini bahwa sistem pengendalian intern pengeluaran kas yang ada pada Sekretariat Daerah Kabupaten Kepulauan Sangihe terdiri dari lima (5) unsur sistem pengendalian intern pemerintah (SPIP) pada PP no 60 tahun 2008 seperti berikut ini.

\section{Lingkungan Pengendalian.}

Berdasarkan hasil wawancara mengenai lingkungan pengendalian bersama dengan Ibu Deasy Tatengkeng selaku Kepala Sub Bagian Keuangan, peneliti menanyakan bagaimana lingkungan pengendalian pada di Sekretariat Daerah? lingkungan pengendalian pada Sekretariat Daerah Kabupaten Kepulauan Sangihe dilihat dari setiap aktivitas kerja. Lingkungan pengendalian menjelaskan dan menguraikan bagaimana prosedur atau kebijakan yang bisa menggambarkan kegiatan kerja pimpinan dan pegawai dalam pencapaian suatu tujuan yang menjadi fondasi dalam 4 (empat) komponen SPIP yang lain. Kegiatan seluruh pegawai selalu dikontrol oleh masing-masing Kepala Bagian agar tidak terjadi kesalahan dalam kinerja pada Sekretariat Daerah. Penelitian ini juga mengkaji mengenai bagaimana lingkungan pengendalian pengeluaran kas pada Sekretariat Daerah? Pimpinan akan merekrut ASN yang memiliki kemampuan yang sesuai dalam pengelolaan keuangan, yang memahami betul mengenai pengelolaan keuangan. Contohnya pimpinan akan merekrut khusus ASN yang memiliki ijazah S1 atau D3 yang sesuai dengan bidangnya dalam prosedur pengelolaan keuangan. Memiliki etika dan bertanggung jawab dalam proses pencatatan pengeluaran kas, pimpinan akan memastikan agar proses pengeluaran kas sudah berdasarkan PP Nomor 58 tahun 2005 tentang pengelolaan keuangan daerah, Permendagri Nomor 13 tahun 2006 tentang pedoman pengelolaan keuangan daerah, dan Permendagri Nomor 59 tahun 2007 tentang perubahan atas permendagri nomor 13 tahun 2006 tentang pedoman pengelolaan keuangan daerah.
Penaksiran Risiko. Berdasarkan hasil wawancara mengenai penaksiran risiko bersama dengan Ibu Deasy Tatengkeng selaku Kasubag Keuangan, peneliti menanyakan risiko apa yang sering terjadi pada proses pengeluaran kas pada Sekretariat Daerah Kabupaten Kepulauan Sangihe? penaksiran risiko yang terjadi khususnya pada setiap kegiatan pengeluaran kas di Sekretariat Daerah Kabupaten Kepulauan Sangihe adalah kesalahan pada pencatatan nominal penggunaan anggaran, kesalahan dalam pencatatan penggunaan anggaran yang sering tercatat dua kali, dan pencatatan tanggal dan waktu yang sering keliru. Peneliti menanyakan juga tindakan apa yang dilakukan ketika timbulnya risiko? tindakan penaksiran risiko bisa dilihat dari Pengguna Anggaran (PA ) memberikan perintah kepada Pejabat Penatausahaan Keuangan (PPK) melakukan verifikasi untuk semua transaksi/belanja yang dibayarkan oleh Bendahara Pengeluaran sesuai dengan aturan dan sesuai dengan program kegiatan yang sudah dianggarkan agar tidak ada kesalahan yang terjadi dalam kegiatan pengeluaran kas.

Aktivitas Pengendalian. Berdasarkan hasil wawancara mengenai aktivitas pengendalian bersama dengan Ibu Deasy Tatengkeng selaku Kasubag Keuangan, peneliti menanyakan bagaimana aktivitas pengendalian pada Sekretariat Daerah? pada Sekretariat Daerah Kabupaten Kepulauan Sangihe pengendalian aktivitas sudah lama diterapkan, tujuannya untuk mengontrol kegiatan yang berlangsung. Terdapat kebijakan atau prosedur dilakukan untuk mempermudah dalam berbagai tindakan ketika mengalami risiko yang muncul dan baru teridentifikasi. Aktivitas pengendalian untuk mendapatkan pengelolaan keuangan khususnya laporan pengeluaran kas yang benar, pemahaman mengenai akuntansi pemerintah sangat penting dimiliki oleh setiap Bendahara Pengeluaran, Pejabat Pelaksana Teknis Kegiatan (PPTK) dan PPK sehingga setiap transaksi keuangan yang dilakukan akan menghasilkan output laporan keuangan yang benar sesuai dengan dasar pengelolaan keuangan yang terpercaya. 
Setiap Kepala Bagian harus memilih ASN yang bertugas dalam pengelolaan pengeluaran kas yang memiliki dasar pengetahuan mengenai pengeluaran kas atau memiliki gelar S1 atau D3 yang sesuai dengan tugas atau tanggung jawab yang diberikan.

Prosedur dalam pencairan anggaran antara lain Bendahara Pengeluaran Pembantu yang memiliki tanggung jawab pada bagian pencairan anggaran harus merampungkan berbagai dokumen seperti Surat Pertanggungjawaban Ganti Uang (SPJGU), Belanja Langsung (LS), dan Tambahan Uang (TU) yang dipakai ketika ada hal yang mendesak. Setelah berbagai berkas telah dirampungkan, Bendahara Pengeluaran Pembantu membuat kwitansi berdasarkan nota atau faktur belanja pada setiap pengeluaran kas kemudian memasukan SPJ untuk diverifikasi pada PPK jika berbagai berkas sebelumnya tidak lengkap, berkas tersebut kembali dievaluasi dan dilengkapi. Jika sudah lengkap Pejabat PPK akan menyetujui dan menandatangani lembar penelitian, setelah itu dilakukan pengambilan nomor register Surat Persetujuan Pembayaran (SPP) dan Surat Perintah Membayar (SPM). Operator Sistem Informasi Manajemen Daerah (SIMDA) mempersiapkan pengetikan SPP dan SPM setelah berkas SPP dan SPM selesai dari pengetikan kemudian diserahkan kepada Staf PPK untuk penandatanganan SPM kepada Kepala Bagian. selanjutnya berkas tersebut diserahkan kepada Badan Keuangan, sesuai dengan SPM Badan Keuangan akan mengeluarkan Surat Perintah Pembayaran Daerah (SP2D) dan diserahkan kepada bank untuk pencairan kas.

Informasi dan komunikasi. Informasi dan komunikasi sangat memiliki pengaruh yang besar terhadap berbagai aktivitas pengelolaan keuangan pada Sekretariat Daerah Kabupaten Kepulauan Sangihe. Informasi dan komunikasi ini sangat membantu dalam aktifitas pengelolaan keuangan yaitu mengidentifikasi dan mencatat semua transaksi yang valid khususnya yang memiliki kaitannya dengan pengeluaran kas, mengklasifikasi transaksi keuangan dengan benar khususnya mengklasifikasi transaksi pengeluaran kas yang sudah mengurangi aktiva pada Sekretariat Daerah Kabupaten Kepulauan Sangihe. Hasil penelitian dengan menggunakan metode wawancara peneliti menanyakan bagaimana informasi pada pengeluaran kas di Sekretariat Daerah? informasi mengenai pencatatan transaksi keuangan contohnya pencatatan transaksi keuangan pada periode akuntansi yang tepat mulai dari pencatatan tanggal agar sesuai dengan waktu transaksi pengeluaran kas, tidak boleh dimanipulasi harus sesuai dengan nota atau cek tanggal yang tertera pada bukti transaksi tersebut. Cek atau nota adalah bukti fisik yang mendukung proses pencatatan agar bisa menyajikan transaksi keuangan khususnya pengeluaran kas dengan tepat dibuktikan dengan adanya dokumen pendukung seperti dokumendokumen yang lain sehingga bisa menghasilkan informasi sesuai fakta agar bisa dicatat dengan baik. Penelitian juga menanyakan bagaimana komunikasi yang berkaitan dengan pengeluaran kas di Sekretariat Daerab? komunikasi yang dibangun dengan baik pada Sekretariat Daerah adalah salah satu kunci dalam menghasilkan laporan keuangan khususnya dalam setiap kegiatan pengeluaran kas contohnya komunikasi antara atasan dan bawahan atau yang lebih spesifik yang berkaitan dengan pengeluaran kas adalah Komunikasi antara Pengguna Anggaran dan Bendahara Pengeluaran Kas agar ketika terdapat kekeliruan atau kesalahan dalam penerimaan informasi.

Pemantauan. Berdasarkan hasil wawancara mengenai pemantauan bersama dengan Ibu Deasy Tatengkeng selaku Kasubag Keuangan, peneliti menanyakan bagaimana pemantauan kinerja pada Sekretariat Daerah? kegiatan atau transaksi keuangan yang rutin dilakukan dalam ruang lingkup pemerintahan adalah pengawasan atau pemantauan. Pengawasan dan pemantauan dilakukan agar bisa menentukan pengendalian intern yang direalisasikan oleh Sekretariat Daerah berjalan dengan baik atau sebaliknya. Peneliti menanyakan juga bagaimana 
pemantauan pengeluaran kas pada Sekretariat Daerah Kabupaten Kepulauan Sangibe? setiap transaksi keuangan mengenai pengeluaran kas akan dilaporkan oleh Bendahara Pengeluaran dan Bendahara Penerimaan dalam bentuk Buku Kas Umum (BKU) kemudian Bendahara kepada pengguna anggaran setiap awal bulan dan untuk memastikan BKU dari Bendahara Pengeluaran sesuai dengan transaksi yang dilakukan. Bendahara Pengeluaran dan Bendahara Penerimaan harus melakukan rekonsiliasi di Badan Keuangan.

Penelitian juga menanyakan dokumendokumen apa yang diawasi dalam pengeluaran kas? dokumen-dokumen pengeluaran kas yang diperhatikan dalam proses pengeluaran kas pada Sekretariat Daerah Kabupaten Kepulauan Sangihe antara lain, bendahara merangkum berbagai keperluan pada nota pesanan agar bisa ditentukan berapa banyak yang diperlukan serta nominal yang akan dianggarkan, serta faktur agar menjadi lembar bukti dalam pembelian barang atau menggunakan anggaran diserahkan kepada Bendahara.

\section{Pembahasan}

\section{Lingkungan}

Pengendalian.

Berdasarkan dengan hasil wawancara sistem pengendalian intern di lingkungan Sekretariat Daerah merupakan kegiatan yang dilakukan secara terus menerus oleh pimpinan dan pegawai pada organisasi untuk memberikan keyakinan yang memadai atas tercapainya tujuan organisasi melalui penerapan kegiatan yang efektif dan efisien, keandalan laporan keuangan, pengamanan aset daerah, dan ketaatan terhadap peraturan perundang-undangan yang berlaku.Dalam hal pengelolaan keuangan yang baik di Sekretariat Daerah hal yang pertama dilakukan adalah menyiapkan sumber daya manusia yang memiliki nilai etis, perilaku yang baik dan memiliki kemampuan dalam memahami mengenai pengelolaan keuangan daerah. Contohnya: Pimpinan akan merekrut ASN sebagai Bendahara Pengeluaran adalah ASN yang mempunyai kompetensi yang tepat, memahami aturan tentang pengelolaan keuangan daerah dan memiliki etika yang baik dan dapat dipercaya. Sistem pengendalian intern di lingkungan Sekretariat Daerah terlihat juga dalam susunan struktur organisasi Sekretariat Daerah di mana dalam struktur organisasi Sekretariat Daerah memberikan suatu kerangka kerja untuk merencanakan, melaksanakan, dan memonitor kinerja. Menetapkan suatu struktur organisasi yang relevan mencakup wewenang dan tanggung jawab, sehingga ASN di Sekretariat Daerah memahami dan mengetahui uraian tugas dan fungsinya yang sudah sesuai dengan unsur Sistem Pengendalian Intern Pemerintah (SPIP).

Penaksiran Risiko. Berdasarkan hasil wawancara penafsiran risiko atau menganalisis berbagai risiko yang akan muncul baik eksternal maupun internal bisa menimbulkan kesalahan dalam pencatatan laporan keuangan khususnya dalam transaksi pengeluaran kas. Penaksiran risiko ini agar pencatatan sesuai dengan prinsip-prinsip akuntansi yang berlaku umum. Pengelolaan keuangan lebih khusus dalam proses pengeluaran kas perlu adanya penaksiran risiko yang mungkin akan timbul dari berbagai transaksi bisa mempengaruhi proses dalam pengelolaan keuangan di Sekretariat Daerah untuk memikirkan risiko apa yang akan terjadi. Untuk menghindari berbagai risiko yang mungkin akan terjadi pada pengelolaan keuangan maka selaku Pengguna Anggaran (PA) memberikan perintah kepada Pejabat Penatausahaan Keuangan (PPK) melakukan verifikasi untuk semua transaksi/ belanja yang dibayarkan oleh Bendahara Pengeluaran sesuai dengan aturan dan sesuai dengan program kegiatan yang sudah dianggarkan. Berbagai tindakan penafsiran risiko tersebut sudah sesuai dengan unsur Sistem Pengendalian Intern Pemerintah (SPIP).

Aktivitas Pengendalian. Berdasarkan hasil wawancara dan observasi aktivitas pengendalian atau identifikasi pengendalian, komponen ini sudah diterapkan pada Sekretariat Daerah Kabupaten Kepulauan Sangihe di mana diketahui bahwa kebijakan atau prosedur yang memiliki fungsi sebagai dasar pengendalian bila terjadi 
penyimpangan atau risiko. Dalam kegiatan akuntansi menggunakan 3 (tiga) cara umum yaitu pemeriksaan kinerja ASN agar menghasilkan kinerja yang berkualitas, pengelolaan informasi khususnya informasi pengeluaran kas, dan pengelolaan fisik dalam pengamanan aset dalam daerah. Untuk mendapatkan pengelolaan keuangan yang benar pengendalian intern terhadap transaksi keuangan sangatlah penting dan rutin. Pemahaman tentang akuntansi pemerintah sangat penting dimiliki oleh setiap Bendahara Pengeluaran, PPTK dan PPK sehingga setiap transaksi keuangan yang dilakukan akan menghasilkan output laporan keuangan yang benar.

Informasi dan komunikasi.

Berdasarkan hasil wawancara dan observasi sistem pengendalian intern terhadap pengelolaan keuangan di lingkungan Sekretariat Daerah memiliki tujuan menghasilkan laporan keuangan yang meliputi sistem akuntansi yang efektif, mudah untuk dimengerti dan sesuai dengan standar akuntansi pemerintah. Sehingga sangatlah penting setiap PPTK memberikan informasi dan mengidentifikasi semua transaksi keuangan. Bendahara pengeluaran dapat menguraikan tepat waktu semua transaksi-transaksi keuangan untuk pelaporan keuangan, contohnya Bendahara Pengeluaran mampu membuat SPJ-TU tepat waktu (satu bulan setelah TU cair). Dan jika ada sisa TU maka Bendahara Pengeluaran harus menyetor ke kas daerah sebelum tanggal jatuh tempo. Dalam hal ini Bendahara Pengeluaran harus mampu menentukan periode waktu transaksi keuangan dalam periode akuntansi yang tepat dan mampu mengukur nilai transaksi keuangan yang wajar dengan tepat yang sesuai dengan unsur Sistem Pengendalian Intern Pemerintah (SPIP).

Pemantauan. Berdasarkan dengan hasil wawancara pemantauan atau pengawasan sudah sesuai dengan unsur SPIP karena pemantauan adalah bagian yang sangat penting mencakup mengawasi kinerja serta mengoreksi berbagai masalah yang berhubungan dengan pengeluaran kas agar menghasilkan kinerja yang berkualitas. Transaksi keuangan akan dilaporkan oleh Bendahara Pengeluaran dan Bendahara Penerimaan dalam BKU, Bendahara kepada pengguna anggaran setiap awal bulan dan untuk memastikan BKU dari Bendahara Pengeluaran sesuai dengan transaksi yang dilakukan. Bendahara Pengeluaran dan Bendahara Penerimaan harus melakukan rekonsiliasi di Badan Keuangan. SPJ yang dibuat oleh Bendahara Pengeluaran/ Bendahara Pengeluaran Pembantu akan diperiksa oleh Inspektorat Kabupaten Kepulauan Sangihe.

\section{Kesimpulan dan saran \\ Kesimpulan}

Kesimpulan yang diperoleh dari hasil penelitian tersebut sistem pengendalian intern pengeluaran kas pada Sekretariat Daerah Kabupaten Kepulauan Sangihe sudah sesuai dengan unsur pengendalian intern menurut Sistem Pengendalian Intern Pemerintah (SPIP) Tetapi belum berjalan secara optimal karena masih terdapat kesalahan yang diakibatkan oleh kurangnya ketelitian pada proses pencatatan oleh bendahara pembantu atau pihak yang bertanggungjawab pada proses pencatatan.

\section{Saran}

1. Saran yang diberikan setelah melakukan penelitian ini adalah pengendalian intern pengeluaran kas di Sekretariat Daerah Kabupaten Kepulauan Sangihe sudah sesuai dengan unsur SPIP pada PP no 60 tahun 2008 tetapi harus lebih teliti dalam proses pencatatan agar tidak terjadi kesalahan. Prosedur pengendalian intern yang baik harus tetap dipertahankan dan lebih ditingkatkan agar berbagai aset maupun aktivitas pengeluaran kas tetap berdasarkan peraturan pemerintah agar menghasilkan pengelolaan keuangan yang efektif dan efisien.

2. Pelatihan rutin bagi Bendahara karena harus ditingkatkan untuk mengikuti peraturan-peraturan yang ada. 


\section{Daftar pustaka}

Effendi, R. (2013). Accounting principle Prinsip akuntansi berbasis SAK ETAP. Edisi Revisi Jakarta: PT. Rajagrafindo Persada.

Kabuhung, M. (2013). Informasi akuntansi penerimaan dan pengeluaran kas untuk perencanaan dan pengendalian keuangan pada organisasi nirlaba Keagamaan. Jurnal EMBA: Jurnal Riset Ekonomi, Manajemen, Bisnis dan Akuntansi, 1(3), 339-348. https://ejournal.unsrat.ac.id/index.php/emba/ar ticle/view/1832

Mulyadi. (2016). Sistem akuntansi. Edisi ke-4. Jakarta: Penerbit Salemba.

Mulyadi. (2013). Sisem akuntansi. Jakarta: Salemba Empat. Mardi. (2011). Sistem informasi akuntansi. Anggota IKAPI: Ghalia. Indonesia.

Ointu, M. R. \& Budiarso, N.S. (2016). evaluasi pelaksanaan sistem dan prosedur pengeluaran kas uang persediaan pada DPPKAD Kab. Boolang Mangondow Selatan. Jurnal EMBA: Jurnal Riset Ekonomi, Manajemen, Bisnis dan Akuntansi, 4(3), 156-164.

https://ejournal.unsrat.ac.id/index.php/emba/ar ticle/view/13662

Peratutan Pemerintah Republik Indonesia Nomor 60 Tahun 2008. Sistem Pengendalian Intern Pemerintah.

Peraturan Pemerintah Nomor 71 Tahun 2010 tentang Standar Akuntansi Pemerintah.

Peraturan Pemerintah Nomor 58 Tahun 2005 tentang Pedoman Keuangan Daerah.

Permendagri Nomor 13 tahun 2006 tentang Pedoman Pengelolaan Keuangan Daerah.

Permendagri Nomor 59 tahun 2007 tentang Perubahan atas Permendagri nomor 13 tahun 2006 tentang Pedoman Pengelolaan Keuangan Daerah.

Sugiyono. (2016). Metode penelitian kuantitatif kualitatif dan kombinasi (mixed methods). Bandung: Alfabeta.

Syarifudin, A. (2014). pengaruh kompetensi sdm dan peran audit intern terhadap kualitas laporan keuangan pemerintah daerah dengan variabel intervening sistem pengendalian internal pemerintah (Studi empiris pada Pemkab Kebumen). Jurnal Fokus Bisnis, 14(02), 26-44.

Tuerah, S. (2013). evaluasi efektifitas sistem informasi akuntansi pembelian dan pengeluaran kas pada UD. Roda Mas Manado. Jurnal EMBA: Jurnal Riset Ekonomi, Manajemen, Bisnis dan Akuntansi, 1(3), 225-232.

Undang-Undang Nomor 29 Tahun 1959 tentang Pembentukan Daerah Tingkat II di Sulawesi Utara.

Undang-Undang Nomor 8 Tahun 2002 tentang Pembentukan Kepulauan Talaud.

Undang-Undang Nomor 15 Tahun 2007 tentang Pembentukan Kabupaten Kepulauan Siau, Tagulandang, Biaro di Provinsi Sulawesi Utara. 